VARIA 


\title{
PARADISE LOST AND THE NARRATION OF NATION IN SALMAN RUSHDIE'S MIDNIGHT'S CHILDREN
}

\author{
Mayra Helena Alves Olalquiaga
}

Mestre em Literatura de Expressão Inglesa-UFMG

\begin{abstract}
This article proposes a study of the appropriations of John Milton's Paradise lost in Salman Rushdie’s Midnight's children. Adapting Milton’s proposition of the “paradise within”, Rushdie explores new ways of viewing imperial national selfrepresentation and how post-colonial writing can relate to its constituting texts.
\end{abstract}

\section{KEYWORDS}

Paradise lost, “paradise within”, Midnight’s children, nation

Although dates and terms are still open to debate, in the contemporary literary landscape the post-colonial literatures have gained prominence. In this process, the postcolonial identity not only of the independent nations after colonialism, but also of the former Empires themselves has been brought into discussion. Attempting to represent the complex interplay of cultural influence that is a consequence of colonialism, and in which literary texts play an important role, writers such as Salman Rushdie can be seen to draw on literary sources from both sides of the former colonial divide.

In Rushdie's Midnight's children, a fictional portrayal of Indian national consolidation after British colonialism, post-colonial national identity is represented through points of contact with John Milton's $17^{\text {th }}$ century epic Paradise lost. Milton's epic can be especially significant to the literatures of former British colonies, for example in novels such as Midnight's children, in which the negotiation of an independent national identity is a central theme, due to its association to a sense of British nation-ness. In the novel, this form of nation-ness lingers on in the affirmation of a national identity on which Indian independence is asserted. 
The association of Paradise lost to a sense of British national identity comes, in large part, from the place attributed to Milton in British cultural production. Paradise lost and its author occupy a central place in imperial national self-representation. And this is a consequence of both the criticism of the epic and of the more elusive role played by nationally defined literatures in national self-representation. Some Milton critics have read into Paradise lost the imperatives of imperial expansion and national consolidation of $17^{\text {th }}$ century Britain, defining these issues as the driving forces behind the text. ${ }^{1}$ For critics like Richard Helgerson, Milton himself has been defined as the successor of the first period (the Elizabethan period) of a conscious effort at constructing a sense of British nation-ness.

This connection of Paradise lost to the emergence of a national consciousness is also part of a more complex, and perhaps less visible process, described by Benedict Anderson in Imagined communities (1991), a study of the emergence of the modern nation. For Anderson, print language becomes the visible symbol that gives a sense of concreteness to a national community that is, in fact, imagined. And the values portrayed in literary texts, and especially in a text like Paradise lost, become the shared common values this community is based on.

Benedict Anderson's Imagined communities analyzes the concept of nation and national affiliations, trying to arrive at a better understanding of the complex set of processes that shape it. In his study, Anderson defines nation not in terms of common language, history, territory, etc., but as a social construct, as a product of a collective imagination. He theorizes the nation as "an imagined political community-and imagined as both inherently limited and sovereign". ${ }^{2}$ Anderson defines the nation in terms of imagination (a term not to be confused with a fabrication or a lie) because all communities larger than direct-contact tribes are imagined, since each member will never know, see or even hear of his fellow citizens. Each member can only imagine their existence and the bond that links them. The nation is limited because each one has a frontier. Nationality cannot be conceived in terms of universality. It is imagined as sovereign because the idea of nation consolidated itself amidst $18^{\text {th }}$ century Enlightenment and the French Revolution, with its banner of freedom and equality whose emblem is a sovereign State ordained by the "people". The nation is imagined as

\footnotetext{
${ }^{1}$ SÁ. Paraíso Perdido em contracena. Uma conversação pós-colonial, p. 15.

${ }^{2}$ ANDERSON. Imagined communities. Reflections on the origin and spread of nationalism, p. 6.
} 
a community because, despite the inequalities and eventual exploitation of certain segments, it is conceived as a brotherhood, a discourse that can lead to extreme acts of killing and dying for it.

For Anderson, the nation was possible due to the fortuitous but explosive interaction between a system of production and productive relations, Capitalism, a technology of communications, print, and the fatality of human linguistic diversity. For Anderson, the way the modern nation is imagined is due to the rise of Capitalism and its first true commodity, mass (re)produced item, the book, and their impact on peoples' imagination and relations. The newly imagined national community of the $18^{\text {th }}$ century was spread by the European powers to their colonies in Africa and Asia in the $19^{\text {th }}$ century, creating artificial boundaries that would influence their construction of a national conscience when these colonies became independent.

This sense of nation-ness, grounded on an ideal common origin and national homogeneity, was spread by the European powers to the colonies through the establishment of European education systems. As Empire was consolidated, literary texts played a role in the process of cementing the sense of the national community, both in the colonial domains and to the members of the European nations themselves.

Taking up Paradise lost, and the representation of nation associated to it, Midnight's children contributes to the discussion of national identity, both Indian and that of the former imperial power. Reading one of the founding texts of British nationality and imperialism, Rushdie examines how the British concept of nation remains a conforming element in the affirmation of independence, as Indian national movements wrote themselves inside the experience of colonialism.

However, although it is a lingering form in post- independence India, the idea of nation-ness described by Anderson and associated to Milton's epic is problematic in Midnight's children. The novel's narrator Saleem Sinai seeks incessantly for a meaning and a form to his life, linking it to the independent nation that is born with him. But as his narrative progresses, Saleem's attempt to negotiate a meaning to his existence tied to the national project ultimately fails. At the end of the novel, Saleem reflects on his life and realizes the mistake he has repeatedly made of "forsak[ing] privacy and be[ing] sucked into the annihilating whirlpool of the multitudes". ${ }^{3}$ In Midnight's children, the writing of national consolidation becomes a writing of its heterogeneity and its splitting

\footnotetext{
${ }^{3}$ RUSHDIE. Midnight's children, p. 533.
} 
differences. And as its heterogeneity becomes explosive and as violence is increasingly used by the “Administration” to maintain national unity, Midnight's children represents nation-ness more and more as an imagined community than a concrete, homogeneous one.

In Midnight's children, the failure to shape a meaning and function to life through the nation leads to a questioning of it and to its characterization as a crumbling “collective dream”, a type of “imagined community” in Anderson's terms. Saleem contrasts the official government discourses on India's brilliant future as an independent nation to the popular riots, the poverty, the struggle for self-determination of minority groups and the many heterogeneous and irreconcilable fragments of India, precariously sewn together by British rule whose influence, even after independence, is impossible to root out. For Saleem India is

\begin{abstract}
A dream we all agreed to dream; it was a mass fantasy shared in varying degrees by Bengali and Punjabi, Madrasi and Jat, and would periodically need the sanctification and renewal which can only be provided by rituals of blood. ${ }^{4}$
\end{abstract}

The breakdown of this very heterogeneous India, masked under an image of homogeneity, is mirrored by Saleem's own gradual decadence. The nation, as it is established, and all the promises born with it are denounced by the narrator and eventually crumble.

Saleem's changed perspective at the end of the novel questions the nation as the privileged space in which the characters negotiate the meanings and forms of their lives. Saleem points to a new perspective on nationality, or a new way of confronting its challenges, that is reminiscent of Milton's proposition of a "paradise within" in Paradise Lost, one that will be fulfilled by the generation following independence.

Midnight's children re-works the ending of Milton's text, re-presenting it in the hands of another A(a)dam. In the novel, Aadam Sinai, the narrator's son, is the representative of the future members of the nation. He presents a version of Milton's idea of the "paradise within" and its associated values and practices as a better positioning before the difficulties in shaping post-colonial identity, both individual and national.

\footnotetext{
${ }^{4}$ RUSHDIE. Midnight's children, p. 124.
} 
In Surprised by sin, Stanley Fish calls the "paradise within", and the new perspective of the world it entails, a "politics of being". It is a commitment to seeing past surface meanings and remaining unaffected by the fluctuations of the world, making instead these fluctuations signify in one direction. It is the collected self that acts with confidence in its integrity. The "politics of being", although based on interiority, is not inertism. It is an active positioning before the world, and so must it be if it is to have any significance. This is the sum of knowledge gained by Adam, after Michael's exposition. He learns to distinguish the misconceptions behind the discourses of great actions and power (Satan's discourse) and advocates the small, daily actions, located in the private sphere of life, as better ways to uprightness. This inner, private sphere is the privileged space in which Man exercises (rightly) his free choice and where "paradise within" is constructed and enjoyed.

The version of "paradise within" in Midnight's children will be fulfilled by the generation represented by Saleem's son, Aadam Sinai. Midnight's children, like Paradise lost, ends with an A[a]dam, marching into the (hopeful) future. For Saleem, the future, as in Milton's epic, is not given or predetermined. His emphasis on the idea that Aadam will forge the future implies not a passive attitude to life, but an active one, involving in this effort both mind and body. This future, for Saleem, will be shaped in the "implacable furnaces of their [future generation's] will". ${ }^{5}$ Although he is also tied to the nation, his father's inevitable legacy, Aadam Sinai presents a different solution to the process of negotiating meaning within the conflicting, heterogeneous elements of India. He is guided by his own will, instead of "looking for [his] fate in prophecy" 6 or in the nation, as Saleem erroneously does. As in Paradise lost, the version of "paradise within” suggested in Rushdie's novel is based on interiority but one that is inserted in a material practice.

In this way, Midnight's children presents its particular take on the epic and reviews, by placing the "paradise within” foremost over the concern with national legitimization, its nationalist associations. Given Paradise lost's standing, the revision of the perception of nation-ness in Midnight's children is directed also at the postcolonial imperial nation. Working Paradise lost into a representation of a former colony's national struggles, Midnight's children highlights to the former Empire it is

\footnotetext{
${ }^{5}$ RUSHDIE. Midnight's children, p. 515.

${ }^{6}$ RUSHDIE. Midnight's children, p. 515.
} 
participation in this history. Furthermore, by using the epic, Rushdie exemplifies how national struggles in a former colony can also be significant to Empire's self understanding. Focusing on the "paradise within" instead of on nationalism, Midnight's children takes Paradise lost out of its assigned role in British national selfunderstanding and opens this understanding to revision.

Suggesting a revision also of imperial national representation, Midnight's children broadens its concerns. Taking up Western or imperial literary conventions, and one of its key texts, Midnight's children refers back also to the former imperial power's process of national self-representation. And by doing this, it recovers and reflects on the role of literature in forming this representation, both in former colonies and the metropolis.

The approach to Midnight's children and to its use of Paradise lost in terms of the influence of colonial forms in post-colonial fictions, however, does not represent an attempt to impose world political issues on Rushdie's novel. Midnight's children has been read in many different ways, in terms of post-modern revision of the separation between historical and literary texts, as a collage of different types of texts, as a representation of post-colonial fragmented Identity, etc. But the nation is the novel's theme, it is the national situation after independence it describes. And it is in this domain that it establishes points of contact with Milton's epic, bringing into discussion the imperial significance of Paradise lost and its associated forms of nation-ness that, for the novel, continue to influence the post-colonial Indian one.

Likewise, the reading proposed here of Paradise lost should not be thought of as an imposition of a political stance on the epic. That is to say, it is not a reading that takes both novel and epic out of their position as literary texts that stand on their own to attribute to them other functions or to close them around political issues outside the sphere of literature. The approach proposed here is rather one way of analyzing how, after colonialism, texts from both sides of the colonial divide can influence each other. As Benedict Anderson has affirmed, literary texts also play a role in shaping the particular kind of consciousness of community that is the nation. Using Paradise lost, Midnight's children brings the discussion of this consciousness to the front, in all its challenges and difficulties of representation, and its significance to literature or, in other words, how literary texts relate to it.

As Midnight's children addresses both the former imperial power, through its use of Paradise lost, and its Eastern domains, the novel also implicitly addresses the 
colonial paradigm that separates East and West. Although Rushdie makes reference to Indian and Western literary texts and sources, it is not to be supposed that a strict separation is made between these two sides of the former colonial divide. This is not the point Midnight's children makes. Rushdie uses these diverse sources to write about a concept that has become common to both, the nation. Drawing on Empire's and on Eastern literary sources in the domain of national representation, and showing how both sides of the colonial divide influence and inform each other through this interweaving of texts, the novel suggests that today strict distinctions no longer hold up. And this is reinforced by the characters in Midnight's children who, like the Rani of Cooch Naheen, gradually turn white, exhibiting on their skin, traditionally the first site on which a strict separation was established, their cross-cultural concerns and identities.

Drawing on Paradise lost in this way, and breaking down the separation established by colonialism between East and West in its discussion of nation, Midnight's children addresses both Eastern and Western audiences. And Rushdie also answers one of the challenges to his work: how writers from former colonial domains, educated inside the former metropolis and who choose English as their language of communication, can represent these peoples. In its representation of nation through points of contact with Paradise lost, and all the implications of this appropriation, Midnight's children can find some ground on which to legitimately write the postcolonial moment.

In its appropriations of Paradise lost, Midnight's children also brings to Milton criticism a new perspective and brings the epic itself new relevance. Taking up Paradise lost to narrate post-colonial India, Midnight's children proposes other ways of analyzing the significance of the poem, its influence outside British literary production and its consequence to the contemporary literary scene in which literatures in English proliferate. Midnight's children's use of Milton's text, as proposed here, brings it into new theoretical and critical domains without imposing on it a time or content specific reading, as has been the tendency in some Milton criticism that imposes a one-sided politics on it, be it Milton's own political views as discussed in his prose work or British imperialism.

But although Rushdie proposes a revision of readings of Paradise lost, Midnight's children is not a criticism of the text or an attack on Empire. Rather, its use of the epic, placing the values and practices of the "paradise within" above the concern 
with national greatness, recovers its full significance, placing it in line with criticism like Stanley Fish’s.

Although Fish's work has been criticized as authoritative and constraining, it sees Paradise lost in the broader terms of corruptibility and the possibility of human improvement. For Fish, the epic would function as a guide without, however, providing exact answers, as to how Man should lead his life and direct his thoughts, collected in himself, so as to follow the will of God. Fish's reading of the epic implies a perspective of active responsibility outside the sphere of power and great politics that the association of the epic to imperialism necessarily implies.

Aadam's recovery and re-working of the idea of the "paradise within”, allowing the novel to address the imperial nation, also becomes a way of contesting some of the criticism directed at Rushdie's work. Using Paradise lost, Midnight's children also inevitably takes up its standing in the British literary canon and its role in defining its sense of nation-ness. Due to this association, writing Indian national struggles with reference to Paradise lost, Rushdie can access this former imperial national selfunderstanding. A reflection on all national projects, Midnight's children responds to some of the criticism directed at its author, that by writing in English and writing the Indian nation on these terms, he is complicit in an ongoing process of cultural neocolonialism.

It could be argued rather that, in its focus on the "paradise within" instead of on national greatness in Paradise lost, and its appropriation of this concept and its spaces as a better positioning before the problems encountered in the nation, Midnight's children brings into question nationally defined literary texts. And, in its use of the imperial epic, Rushdie's novel exemplifies the ways such fiction can be brought into dialogue with texts from the former colonial domains, suggesting new possibilities of influence between them.

\section{RESUMO}

Este artigo estuda a apropriação do poema épico Inglês Paradise lost no romance Midnight's children, de Salman Rushdie. Adaptando o conceito de "paradise within”, Rushdie explora novas maneiras de ver a representação nacional da metrópole e como textos pós-coloniais podem se posicionar em relação aos textos que a constituem. 


\section{PALAVRAS-CHAVE}

Paradise lost, “paradise within”, Midnight's children, nação

\section{REFERENCES}

ANDERSON, Benedict. Imagined communities. Reflections on the origin and spread of nationalism. London/New York: Verso, 1991.

FISH, Stanley Eugene. Surprised by sin: the reader in Paradise lost. $2^{\text {nd }}$ ed. Cambridge: Harvard UP. 1998.

HELGERSON, Richard. Forms of nationhood: the Elizabethan writing of England. Chicago: University of Chicago Press, 1992.

MILTON, John. Paradise lost. Ed. John Leonard. London: Penguin Classics, 200

RUSHDIE, Salman. Midnight's children. New York: Penguin, 1980.

SÁ, Luiz Fernando Ferreira. Paraíso perdido em contracena. Uma conversação póscolonial. 2001. 222 f. Tese (Doutorado) - Faculdade de Letras, Universidade Federal de Minas Gerais, Belo horizonte, 2001. 